\title{
Distribution of Collagenase in the Digestive Organs of Some Teleosts*1
}

\author{
Reiji YoshinaKA*2, Mamoru SATO*3, and Shizunori IKEDA*2 \\ (Received September 14, 1977)
}

\begin{abstract}
Collagenolytic activity was found to be present in various digestive organs of nineteen species of teleost. The activity was detected in the pancreas, the pyloric caeca together with the surrounding fatty tissue, the intestine, the mesentery, and the mesenteric and fatty tissue around the intestine. When considered together with the fact that the pancreatic tissue is diffuse in many teleosts, these findings suggest that collagenase originates from the pancreas.

In the cases of rainbow trout and yellow-tail, collagenase was detected in the fatty tissue between the pyloric caeca rather than in the caeca themselves. These findings substantiate the theory that collagenase is of pancreatic origin, since the pancreatic tissue is embedded in the fatty tissue between the caeca.

In addition, it was observed that the collagenolytic activity in the digestive system of the fishes examined could be correlated to their usual diet in nature.
\end{abstract}

Although a collagenase has been demonstrated in the pyloric caeca of yellow-tail, Seriola quinqueradiata $^{1-31}$, there is still no evidence as to the exact localization of the source of this enzyme. In addition, it is also not clear whether collagenase is present in the digestive system of other fishes.

There are certain important differences in the digestive system of the teleost species. Some teleosts, for example the Cyprinidae, have no stomach. Most teleosts have the diffuse pancreas and only a few species have more or less compact pancreas. Many teleosts have the pyloric caeca but some fishes lack them. Because of such variations, it has been pointed out that the exact localization of the source of digestive enzymes is difficuit ${ }^{4}$.

In the present study, it was attempted to clarify the production site of digestive collagenase on the basis of its distribution among various digestive organs of the different species which differ in the structure of the digestive system. In addition, the relationship between the total activity of collagenase in the digestive system of the species examined and their natural diet is described in this paper.

\section{Materials and Methods}

Fishes

The fishes used for the present study were as follows: sardine, Sardinops melanosticta, rainbow trout, Salmo gairdnerii, amago, Oncorhynchus mason macrostomus, ayu, Plecoglossus altivelis, gengorobuna, Carassius carassius cuvieri, ginbuna, Carassius carassius langsdorfii, carp, Cyprinus carpio, ugui, Tribolodon hakonensis, wataka, Ischikausia steenackerii, catfish, Parasilurus asotus, eel, Anguilla japonica, half-beak fish, Hemiramphus sajori, kisu, Sillago sihama, red sea bream, Pagrus major, jack mackerel, Trachurus japonicus, yellowtail, Seriola quinqueradiata, bluefin tuna, Thunnus thynnus, umazurahagi, Novodon modestus, and shotted halibut, Eopsetta grigorjewi. Gengorobuna, ginbuna, ugui, and wataka were caught in a creek of Lake Biwa. Carp and eel were obtained from a local fish farm and rainbow trout and amago from Shiga Prefectural Trout Culture Experimental Station at Samegai. They were kept in the aquarium in our laboratory and were fed until the day before use. The Cyprinidae were fed on a commercial diet for carp, rainbow trout and amago on a commercial diet for rainbow trout, and eel on the meat of short-necked clam, Tapes philippinarum. Ayu were caught in a river near Maizuru Bay early in June, stored immediately in an ice box, and used for assay the next day. Catfish and umazurahagi were obtained alive from a commercial supplier. The former were kept without feeding in an aquarium for 2 days; the latter were used immediately after their arrival at our laboratory. Other fishes, which were bought in the fish markets of Maizuru and Kyoto, were not alive

*1 Studies on Collagenase in Fish-IV.

*2 Dept. Fish., Fac. Agr., Kyoto Univ., Kyoto, Japan (吉中禮二・佐藤 守・池田静德： 京都大学贯学部). 
and were either in a pre- or rigor mortis conditions.

\section{Preparation of Enzyme Solution}

The alimentary canal and the Jiver or the hepatopancreas were removed. In many cases the alimentary canal was separated into three groups: the stomach, the pyloric caeca, and the intestine. The pyloric casca of many species examined were surm rounded with the fatty tissue, while those of red sea bream and shotted halibut were not. In the present paper, the pyloric caeca together with the surrounding fatty tissue in the former case are reforred to as the whole pyloric caeca, which are distinguished from the pyloric caeca in the latter case. In some cases the mesenteric and fatty tissue investing the intestine was separated and in a fow cases the pancreas and the mesentery were excised. Any contents in the stomach and the intestine were gently squeezed out, while those in the caeca were not.

In another experiment, the whole pyloric caeca of rainbow trout and yellow-tail were carefully dissected into the caeca themselves and the surrounding fatty tissue. In this case the lumen contents in the individual caeca were squeezed out.

Each tissue was homogenized in 5-7 vol. of cold $0.05 \mathrm{M}$ Tris-HCl buffer, $\mathrm{pH} 7.5$, containing $5 \mathrm{~mm}$ $\mathrm{CaCl}_{2}$ with a Polytron homogenizer, KINEMATICA GMBH, Luzern, Switzerland. The homogenate was centrifuged in the cold at $15,000 \times \mathrm{g}$ for $20 \mathrm{~min}$, and the supernatant was filtered through cotton wool to remove lipid materials present at the surface. The filtrate was dialyzed against the same buffer overnight in a cold room $\left(5^{\circ} \mathrm{C}\right)$ and centrifuged again at $15,000 \times \mathrm{g}$ for $20 \mathrm{~min}$. This dialyzed preparation was used as the enzyme solution.

\section{Assay Procedures}

Collagenolytic activity was determined by the release of soluble fragments from reconstituted carp skin collagen fibrils at $\mathbf{p H} 7.5$ as described previously ${ }^{1,21}$. Protein was determined by the method of LownY et $a l^{\overline{5}}{ }^{\text {' }}$ and hydroxyproline by the method of WoEssNer. ${ }^{61}$

\section{Results and Discussion}

\section{Distribution of Collagenolytic Activity in the Digestive Organs of Fishes}

Table 1 shows the distribution of collagenolytic activity in the digestive organs of eleven typical species out of nineteen species of the fishes examined. In many cases relatively high collagenoly- tic activity was detected in the intestine but none in the stomach. However, no activity was found in the intestine of bluefin tuna and umazurahagi; relatively low activity was found in the stomach of eel and shotted halibut.

With the exception of red sea bream and kisu, which had high collagenolytic activity in the hepatopancreas, no or little activity was detected in the liver or the hepatopancreas of the fishes.

In all cases examined, relatively high collagenolytic activity was detected in the whole pyloric caeca, the pyloric caeca, and the mesenteric and fatty tissue. In catfish and eel, which have the compact pancreas, high collagenolytic activity was detected in that organ. The level of the activity in the pancreas of catfish was remarkably higher than that in any organ of the fishes examined. In a case of umazurahagi high collagenolytic activity was found only in the mesentery.

In the cases of other species examined, which are not shown in Table 1, collagenolytic activity was mainly detected in the whole pyloric caeca, the intestine, and the mesenteric and fatty tissue.

It is well-known that many teleosts have the diffuse pancreas and only a few species, e.g., catfish and eel, have the compact pancreas. In the former group, the pancreatic tissue is partly situated along the portal veins and extends into the liver, and is partly suspended in the mesenteric and fatty tissue around the intestine. In the fishes having the pyloric caeca the pancreatic tissue is also located between the caeca. Therefore, it seems reasonable to consider that collagenase originates exclusively from the pancreatic tissue, since collagenolytic activity was detected in the compact pancreas and in the organs which are considered to include the adhering pancreatic tissue. The activity often found in the intestine might be caused by pancreatic collagenase which was previously absorbed by the intestinal mucosa or was derived from the pancreatic tissue around the intestine since it was impossible to separate completely the intestinal contents and the surrounding tissue from the intestine.

\section{Occurrence of Collagenase in the Whole Pyloric Caeca}

The histology of the pyloric caeca of rainbow trout and yellow-tail was studied by WEINREB and BILSTAD $^{71}$ for the former and Kimura" for the latter, who identified the pancreatic tissue enbedded in the fatty tissue between the caeca. It was, therefore, considered that collagenolytic activity detected in the whole pyloric caeca of both 
Table 1. The distribution of collagenolytic activity in the digestive organs of various species of fish

\begin{tabular}{|c|c|c|c|c|}
\hline \multirow{2}{*}{ Species } & \multirow{2}{*}{ Organ } & \multirow{2}{*}{$\begin{array}{l}\text { Tissue } \\
\text { weight } \\
\text { (g) }\end{array}$} & \multicolumn{2}{|c|}{ Collagenolytic activity*1 } \\
\hline & & & per g tissue & per mg of protein \\
\hline \multirow{2}{*}{$\begin{array}{l}\text { Sardine } \\
\quad \text { Sardinops melanosticta }\end{array}$} & Liver & 2.50 & N.D. $* 2$ & N.D. \\
\hline & Stomach & 1.47 & N.D. & N.D. \\
\hline B. W. $168.0 \mathrm{~g}$ & Intestine & 0.70 & 538.7 & 34.3 \\
\hline \multirow[t]{2}{*}{ B. L. $\quad 22.5 \mathrm{~cm}$} & Whole pyloric caeca & 1.82 & 718.4 & 53.5 \\
\hline & Mesenteric and fatty tissue & 1.05 & 192.4 & 5.1 \\
\hline Rainbow trout & Liver & 3.65 & 33.7 & 2.0 \\
\hline Salmo gairdnerii & Stomach & 5.77 & N.D. & N.D. \\
\hline B. W. $370.0 \mathrm{~g}$ & Intestine & 1.78 & 554.1 & 36.8 \\
\hline \multirow[t]{2}{*}{ B. L. $27.0 \mathrm{~cm}$} & Whole pyloric caeca & 5.55 & 846.9 & 81.2 \\
\hline & Mesenteric and fatty tissue & 4.70 & 469.8 & 124.9 \\
\hline Ginbuna & Liver & 2.55 & N.D. & N.D. \\
\hline \multirow{2}{*}{$\begin{array}{l}\text { Carassius carassius } \\
\text { langsdorfii }\end{array}$} & Intestine & & & \\
\hline & anterior & 0.57 & 91.0 & 4.8 \\
\hline \multicolumn{5}{|l|}{ B. L. $16.5 \mathrm{~cm}$} \\
\hline Carp & Hepatopancreas & 2.20 & 60.6 & 12.0 \\
\hline Cyprinus corpio & Intestine & & & \\
\hline B. W. $\quad 97.0 \mathrm{~g}$ & anterjor & $1.4 \mathbf{i}$ & N.D. & N.D. \\
\hline \multirow[t]{2}{*}{ B. L. $\quad 15.0 \mathrm{~cm}$} & posterior & 0.66 & 57.6 & 10.4 \\
\hline & Mesenteric and fatty tissue & 1.98 & 113.1 & 22.5 \\
\hline Catfish & Liver & 2.60 & 56.6 & 1.4 \\
\hline Parasilurus asotus & Stomach & 3.00 & N.D. & N.D. \\
\hline B. W. $214.0 \mathrm{~g}$ & Intestine & 1.33 & 108.7 & 3.1 \\
\hline B. L. $\quad 31.0 \mathrm{~cm}$ & Pancreas & 0.41 & 103064.6 & 2615.4 \\
\hline Eel & Liver & 2.70 & N.D. & N.D. \\
\hline Anguilla japonica & Stomach & 1.30 & 45.8 & 1.1 \\
\hline B. W. $152.6 \mathrm{~g}$ & Intestine & 1.40 & 514.1 & 33.9 \\
\hline B. L. $\quad 48.3 \mathrm{~cm}$ & Pancreas & 0.38 & 2446.5 & 162.0 \\
\hline Red sea bream & Hepatopancreas & 1.95 & 1702.4 & 71.8 \\
\hline Pagrus major & Stomach & 1.04 & N.D. & N.D. \\
\hline B. W. $248.0 \mathrm{~g}$ & Intestine & 3.12 & 101.7 & 9.9 \\
\hline B. L. $\quad 21.5 \mathrm{~cm}$ & Pyloric caeca & 0.31 & 412.6 & 47.4 \\
\hline Yellow-tail & Liver & 19.40 & N.D. & N.D. \\
\hline Seriola quinqueradiasa & Stomach & 10.60 & N.D. & N.D. \\
\hline B. W. $1100.0 \mathrm{~g}$ & Intestine & 2.80 & 631.2 & 70.4 \\
\hline B. L. $\quad 38.0 \mathrm{~cm}$ & Whole pyloric caeca & 31.85 & 580.8 & 155.3 \\
\hline Bluefin tuna & Liver & 30.50 & N.D. & N.D. \\
\hline Thunnus thynnus & Stomach & 26.80 & N.D. & N.D. \\
\hline B. W. $1547.0 \mathrm{~g}$ & Intestine & 3.10 & N.D. & N.D. \\
\hline B. L. $41.5 \mathrm{~cm}$ & Whole pyloric caeca & 38.70 & 1809.1 & 102.9 \\
\hline Umazurahagi & Hepatopancreas & 4.90 & N.D. & N.D. \\
\hline Novodon modestus & Intestine & & & \\
\hline B. W. $138.0 \mathrm{~g}$ & anterior & 1.13 & N.D. & N.D. \\
\hline B. L. $\quad 21.5 \mathrm{~cm}$ & posterior & 1.68 & N.D. & N.D. \\
\hline & Mesentery & 0.30 & 684.1 & 57.7 \\
\hline Shotted halibut & Hepatopancreas & 8.27 & N.D. & N.D. \\
\hline Eopsetta grigorjewi & Stomach & 2.62 & 255.9 & 5.2 \\
\hline B. W. $398.0 \mathrm{~g}$ & Intestine & 1.24 & 808.1 & 66.3 \\
\hline B. L. $\quad 27.7 \mathrm{~cm}$ & Pyloric caeca & 0.80 & 1316.5 & 82.8 \\
\hline
\end{tabular}


Table 2. The occurrence of collagenase in the whole pyloric caeca of rainbow trout and yellow-tail

\begin{tabular}{|c|c|c|c|c|}
\hline \multirow{2}{*}{ Species } & \multirow{2}{*}{ Tissue } & \multirow{2}{*}{$\begin{array}{l}\text { Tissue } \\
\text { weight } \\
\text { (g) }\end{array}$} & \multicolumn{2}{|c|}{ Collagenolytic activity*1 } \\
\hline & & & per $g$ of tissue & per mg of protein \\
\hline Rainbow trout $* 2$ & Pyloric caeca & 0.50 & 740.5 & 50.5 \\
\hline Salmo gairdnerii & Fatty tissue & 0.64 & 3743.8 & 155.8 \\
\hline Yellow-tail*8 & Pyloric caeca & 5.80 & 20.2 & 0.7 \\
\hline Seriola quinqueradiata & Fatty tissue & 11.90 & 1439.4 & 358.1 \\
\hline
\end{tabular}

Table 3. Total collagenolytic activity in the digestive system of various fishes and their usual diet in nature

\begin{tabular}{|c|c|c|}
\hline Species & $\begin{array}{c}\text { Total } \\
\text { activity"1 }\end{array}$ & Usual diet in nature \\
\hline $\begin{array}{l}\text { Catfish, Parasilurus asotus } \\
\text { (B. W. } 214.0 \mathrm{~g} \text { ) }\end{array}$ & 19882 & Crustacean, fish $* 2$ \\
\hline $\begin{array}{l}\text { Bluefin tuna, Thumnus thynnus } \\
\text { (B. W. } 1547.0 \mathrm{~g} \text { ) }\end{array}$ & 4526 & Fish $^{* 2}$ \\
\hline $\begin{array}{l}\text { Jack mackerel, Trachurus japonicus } \\
\text { (B. W. } 238.0 \mathrm{~g} \text { ) }\end{array}$ & 2706 & Crustacean, larval fish*2 \\
\hline $\begin{array}{l}\text { Rainbow trout, Salmo gairdnerii } \\
\text { (B. W. } 370.0 \mathrm{~g})\end{array}$ & 2167 & Insect, crustacean ${ }^{* 2}$ \\
\hline $\begin{array}{l}\text { Yellow-tail, Seriola quinqueradiata } \\
\text { (B. W. } 1100.0 \mathrm{~g})\end{array}$ & 1842 & Fish, cuttle-fish*2 \\
\hline $\begin{array}{l}\text { Amago, Oncorhynchus masou macrostomus } \\
\text { (B. W. } \quad 77.0 \mathrm{~g})\end{array}$ & 1768 & Insect ${ }^{* 8}$ \\
\hline $\begin{array}{l}\text { Red sea bream, Pagrus major } \\
\quad \text { (B. W. } 248.0 \mathrm{~g} \text { ) }\end{array}$ & 1518 & Crustacean, polychaete, bivalye*s \\
\hline $\begin{array}{l}\text { Ayu, Plecoglossus altivelis } \\
\text { (B. W. } 7.9 \mathrm{~g} \text { ) }\end{array}$ & 1287 & $\begin{array}{l}\text { Crustacean (young) }{ }^{* 2} \\
\text { Diatom, blue-green algae (adult) }{ }^{* 2}\end{array}$ \\
\hline $\begin{array}{l}\text { Sardine, Sardinops melanosticta } \\
\text { (B. W. } 168.0 \mathrm{~g} \text { ) }\end{array}$ & 1123 & Diatom, crustacean ${ }^{* 2}$ \\
\hline $\begin{array}{l}\text { Eel, Anguilla japonica } \\
\text { (B.W. } 152.6 \mathrm{~g})\end{array}$ & 1120 & Polychaete, crustacean, fish*3 \\
\hline $\begin{array}{l}\text { Half-beak fish, Hemiramphus sajori } \\
\text { (B. W. } 76.0 \mathrm{~g} \text { ) }\end{array}$ & 759 & Crustacean $^{* 2}$ \\
\hline $\begin{array}{l}\text { Ugui, Tribolodon hakonensis } \\
\text { (B. W. } 122.0 \mathrm{~g})\end{array}$ & 709 & Vegetable and animal matters*2 \\
\hline $\begin{array}{l}\text { Kisu, sillago sihama } \\
\text { (B. W. } 47.0 \mathrm{~g} \text { ) }\end{array}$ & 701 & Polychaete, crustacean $* 4$ \\
\hline $\begin{array}{l}\text { Shotted halibut, Eopsetta grigorjewi } \\
\text { (B. W. } 398.0 \mathrm{~g} \text { ) }\end{array}$ & 685 & Crustaceant*3 \\
\hline $\begin{array}{l}\text { Gengorobuna, Carassius carassius cuvieri } \\
\text { (B. W. } 143.0 \mathrm{~g} \text { ) }\end{array}$ & 562 & Vegetable and animal matters $* 2$ \\
\hline $\begin{array}{l}\text { Carp, Cyprinus carpio } \\
\text { (B. W. } 97.0 \mathrm{~g})\end{array}$ & 408 & Vegetable and animal matters $* 2$ \\
\hline $\begin{array}{l}\text { Wataka, Ischikausia steenackerï } \\
\text { (B. W. } 87.0 \mathrm{~g})\end{array}$ & 162 & Waterweed $* 5$ \\
\hline $\begin{array}{l}\text { Umazurahagi, Novodon modestus } \\
\text { (B. W. } 138.0 \mathrm{~g} \text { ) }\end{array}$ & 149 & Polychaete, crustacean*6 \\
\hline $\begin{array}{l}\text { Ginbuna, Carassius carassius langsdorfii } \\
\text { (B. W. } 88.0 \mathrm{~g} \text { ) }\end{array}$ & 126 & Vegetable and animal matters $* 2$ \\
\hline 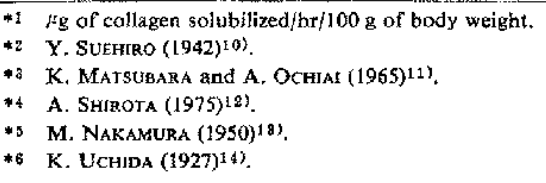 & & \\
\hline
\end{tabular}


species may have been derived from the pancreatic tissue surrounding the caeca. In order to confirm the exact localization of the source of this enzyme, we attempted to separate the fatty tissue including the pancreatic tissue from the caeca themselves and then to assay the activity in both fractions. As shown in Table 2, in both cases of rainbow trout and yellow-tail, high collagenolytic activity was detected in the fatty tissue, while only low activity was detected in the caeca themselves. The occurrence of the activity in the caeca might be explained by assuming that the caeca was contaminated by a trace of the lumen contents or the fatty tissue, since it was not easy to remove them from the caeca.

This finding indicates that collagenolytic activity detected in the whole pyloric caeca originates from the pancreatic tissue, and also provides evidence supporting the above indication that collagenase in the digestive system of fishes is possibly of pancreatic origin. In addition, although in the previous studies on collagenase isolated from the whole pyloric caeca of yellowtail $^{1-31}$ we regarded it as a caecal enzyme, the result obtained in the present study indicates that our misunderstanding about the enzyme origin in the previous papers ${ }^{1-31}$ should be corrected.

\section{Correlation Between Collagenolytic Activity and the Natural Diet}

As pointed out by many workers ${ }^{4.91}$, the production of digestive enzymes of fish is correlated with the composition of the normal diet. Even the fishes examined in the present study show great diversity with regard to their natural diet. It was, therefore, expected that the activity of collagenase in the digestive system of fish might be adapted to the usual diet in nature. In order to confirm such a relationship, total collagenolytic activity in the digestive system of each species was estimated by summing up the activity in all the organs assayed and by being expressed in the amount of the activity per $100 \mathrm{~g}$ of body weight. Table 3 shows collagenolytic activity in the digestive system of fishes with their usual diet presented by several authers ${ }^{10-141}$. It may be not entirely reasonable to make a comparison between fish species with respect to the level of collagenase on the basis of the data obtained from one sample of each species, because the production of degestive enzymes is affected by the physiological conditions of fish which are influenced by nutritional state, season, age, and so on. However, ascan be seen in Table 3, the amount of collagenase in the digestive system was roughly correlated with the natural diet. As a general rule, the level of digestive collagenase was found to be higher in the carnivores feeding on the diet rich in collagen than in the omnivores and herbivores on the diet poor or lacking in collagen. The result presented here indicates that digestive collagenase of fish is adapted to some extent to the usual diet and also supports the view pointed out by many workers that the production of digestive enzymes is correlated with the diet ${ }^{4,9}$.

\section{Acknowledgement}

The authers thank Professor T. Iwai, Department of Fisheries, Kyoto University, for his valuable suggestion as to the histology of fish.

\section{References}

1) R. Yoshinaka, M. Sato, and S. IKEda: Bull. Japan. Soc. Sci. Fish., 39, 275-281 (1973).

2) R. Yoshinaka, M.SAto, and S. Ikena: Bull. Japan. Soc. Sci. Fish., 42, 455-463 (1976).

3) R. Yoshinaka, M. Sato, and S. IKeda: Bull. Japan. Soc. Sci. Fish., 43, 1195-1201 (1977).

4) B. G. KAPOOR, H. Smit, and J. A. Verighina: Adv. Mar. Biol., 13, 109-239 (1975).

5) O. H. Lowry, N. J. Rosebrough, A. L. FarR, and R. J. RaNDALL: J. Biol. Chem., 193, 265275 (1951).

6) J. F. Woessner, JR.: Arch. Biochem. Biophys., 93, 440-447 (1961).

7) L. WeinReb and N. M. Bulstad: Copeia, 1955(3) 194-204 (1955).

8) M. Kimura: Bull. Fac. Agr., Univ. Miyazaki, 15, 81-175 (1968).

9) E.J. W. Barrington: in "The Physiology of Fish" (ed. by M. E. Brown), Yol. I, Academic Press, New York, 1957, pp. 109-161.

10) Y. Suehiro: Japan. J. Zool, 10, 1-303 (1942).

11) K. Matsubara and A. OCHIAI: Ichthyology (Part II), Ist ed., Koseisha-Koseikaku, Tokyo, 1965.

12) A. Shrota: Fresh-Marine Organisms as Living Feed for Fisheries, 1st ed., Koseisha-Koseikaku, Tokyo, 1975, pp. 116-133.

13) M. Nakamtra: Bull. Japan. Soc. Sci. Fish., 15, 833-840 (1950).

14) K. UCerda; Dobutsugaku Zasshi, 39, 161-178 (1927). 